Environmental Biology of Fishes

Volume 78, Number 2 / February, 2007 : 93-105

http://dx.doi.org/ 10.1007/s10641-006-9042-3

(c)2007 Springer Science+Business Media
Archimer, archive institutionnelle de l'Ifremer http://www.ifremer.fr/docelec/

\title{
Eel community structure, fluvial recruitment of Anguilla marmorata and indication for a weak local production of spawners from rivers of Réunion and Mauritius islands
}

\author{
Tony Robinet ${ }^{1,{ }^{*}}$, Eric Feunteun ${ }^{2}$, Philippe Keith ${ }^{3}$, Gérard Marquet ${ }^{4}$, Jean-Michel Olivier ${ }^{5}$, \\ Elodie Réveillac ${ }^{2}$ and Pierre Valade ${ }^{6}$
}

1) Ocean Research Institute (Behavior and Ecology Group), University of Tokyo, 1-15-1 Minamidai, Nakano-ku, 164-8639 Tokyo, Japan

(2) Centre de Recherche sur les Ecosystèmes Littoraux Anthropisés (CRELA), UMR6217 CNRS-IFREMER-

Université de La Rochelle, rue Enrico Fermi, 17000 La Rochelle, France

(3) Muséum National d'Histoire Naturelle, Ichtyologie, DMPA CP026, 57 rue Cuvier, 75231 Paris cedex 05,

France

(4) Rue des Papangues, 97460 Saint-Paul, Ile de La Réunion, France

(5) Ecologie des Hydrosystèmes Fluviaux, UMR CNRS 5023 - Université de Lyon I, 43 Bd du 11 novembre 1918, 69622 Villeurbanne Cedex, France

(6) Association Réunionnaise de Développement de l'Aquaculture (ARDA), Centre des Eaux Douces, Les Sables, 97427 Etang-Salé, Ile de La Réunion, France

*: Corresponding author : tony.robinet@wanadoo.fr

\begin{abstract}
:
Anguillid eels were sampled from permanent rivers in the Réunion and Mauritius islands, western Indian Ocean, with a standardized electrofishing method. A. marmorata was very dominant, corresponding to 91.7 and $90.7 \%$ of all the eels collected in Réunion and Mauritius, respectively. Three other species (A. mossambica, A. bicolor bicolor and A. nebulosa labiata) were also present in both islands. A. marmorata showed a strong altitudinal gradient of densities from the lower to upper zones, especially in the younger stages $(T L<250 \mathrm{~mm})$, while A. mossambica was only found in the upper zones and A. bicolor bicolor occurred only in the lower zones (A. nebulosa labiata was rare). The eel species composition in freshwaters of both islands is very similar because these two adjoining islands are located in the same trail of drifting marine larvae. Mean estimated eel biomasses were noticeably low (11.1 and $22.2 \mathrm{~kg}$ ha-1 in Réunion and Mauritius islands, respectively), especially when compared to those of other tropical insular systems without any eel fishery (Comoros or Polynesia, more than $100 \mathrm{~kg} \mathrm{ha}-1$ ). Nevertheless, the fluvial recruitment of A. marmorata seemed to be regular during the surveyed period, staggering from October to April. The obvious lack of large eels in Mauritius but more significantly in Réunion suggests a high pressure from traditional fishery, and the local reproductive turnover is uncertain. Because sexual maturation seems to occur at a large body size for A. marmorata, as for temperate species, the Réunion and Mauritius rivers may only have a weak contribution to the regional production of spawners. However, the giant mottled eel population in the western Indian Ocean is believed to be panmictic at the regional scale, and may not rely exclusively on these islands' contribution. A comparison is made with those of freshwater systems in other tropical islands.
\end{abstract}

Keywords: Tropical eels - Indian Ocean - Fluvial recruitment - Reproductive turnover - Conservation 


\section{Introduction}

Four Anguillid eel species (Anguilla bicolor bicolor McClelland 1844, A. marmorata Quoy \& Gaymard 1824, A. mossambica Peters 1852 and A. nebulosa labiata Peters 1852) occur in the western Indian Ocean (Ege 1939). The spawning area of these catadromous fishes is believed to be somewhere in the northeastern waters of Madagascar (Jubb 1961, Miller 2003, Robinet et al. 2003a). In the continental and insular freshwaters surrounding this region, the composition of eels communities are more or less contrasted, due to different drifting routes of marine eel larvae before their estuarine recruitment. Anguilla mossambica largely dominates in South Africa (Jubb 1960, Bruton et al. 1987), whereas A. nebulosa labiata is reported as the dominant eel species in Kenya rivers (Frost 1954), but seems relatively rare in Madagascar (Moreau 1987). Conversely, A. marmorata is well represented in this large island. A. bicolor bicolor is exclusively distributed in the northern part of the area, and is the only eel species occurring in the Seychelles archipelago (Valade \& Feunteun, unpubl. data).

At about $600 \mathrm{~km}$ far east from Madagascar, the Réunion and Mauritius twin islands are orientated south-southeastern from the hypothetical spawning areas, and $200 \mathrm{~km}$ one from each other. If the eel species communities of Réunion and Mauritius are supposed to be similar, they are not precisely known yet. Kiener \& Duchochois (1981), Marquet et al. (1997) and Keith et al. (1999) notified the presence of 4 eel species in the Réunion freshwaters, without precisions on the species proportion nor on their local population structure. In Mauritius rivers, the different eel species were progressively reported by Gudger (1929), Blanc \& Postel (1958), Starmülhner (1979) and Baissac (1990), but no information about the populations structure has been published yet.

Anguilla marmorata Quoy \& Gaimard 1824, the giant mottled eel, is the Anguillid eel species with the widest distribution area in the world. Its Indo-Pacific distribution ranges from the East African coast (Ege 1939, Jubb 1961), Indonesia and Philippines (Budimawan 1997), Southeastern Asia and North Pacific (Nishi \& Imai 1969, Williamson \& Boëtius 1993, Tzeng et al. 1995) to South Pacific (Jellyman 1987, Marquet et al. 1997) and French Polynesia (Marquet and Galzin 1991). Moreover, A. marmorata is the only eel species for which 5 distinct populations are known (Ishikawa et al. 2004), one of them surrounding Madagascar. Most studies on A. marmorata have focused on its early life history (Tabeta et al. 1976, Aoyama et al. 1999, Arai et al. 1999, Robinet et al. 2003a). In contrast, its inland freshwater life - i.e. fluvial recruitment, feeding ecology, growth dynamics, dwelling or nomadic behavior, insular and continental production of breeders - remains largely unknown. Only Marquet (1987) and Marquet \& Galzin (1991) studied A. marmorata ecology in South-Pacific islands, whereas Robinet et al. (2003b) described the upstream migration dynamics in the Réunion Island.

In this study, we analyze and compare the Anguillid eels community structure in Réunion and Mauritius islands. We particularly focus on the dominant species A. marmorata, by analyzing the fluvial recruitment rhythm in the Réunion Island, based on the relatively high mean growth rate for yellow eels and on length-frequency diagrams decomposition. This fluvial population structure is then compared with those of freshwater systems in other tropical islands.

\section{Material and Methods}

Study sites

The Réunion and Mauritius islands $\left(21.0^{\circ} \mathrm{S}-55.5^{\circ} \mathrm{E}\right.$ and $\left.20.0^{\circ} \mathrm{S}-57.0^{\circ} \mathrm{E}\right)$ are recent volcanic formation in the southwest Indian Ocean. These islands were formed 10 My (Mauritius) and 
2.1 My ago (Réunion, Dercourt 1997). Réunion $\left(2507 \mathrm{~km}^{2}\right)$ is the highest island and hosts 13 permanent rivers, with surfaces ranging from $15 \mathrm{~km}^{2}$ (River Bras-Panon) to $145 \mathrm{~km}^{2}$ (River $\mathrm{du}$ Mat, Figure 1). Headwaters all originate in one of the 3 volcanic cirques, $700-1000 \mathrm{~m}$ above sea level, or in the altitudinal forests that cover mountains slopes. The water flow is usually low between May and October $\left(0.10-0.25 \mathrm{~m}^{3} \cdot \mathrm{s}^{-1} \cdot \mathrm{km}^{-2}\right)$, but it can very suddenly rise up to more than $10-20 \mathrm{~m}^{3} \cdot \mathrm{s}^{-1} \cdot \mathrm{km}^{-2}$ during the cyclonic season from December to April (2 500 $\mathrm{m}^{3} \cdot \mathrm{s}^{-1}$ recorded in the River du Mat, Hyacinth cyclone in 1980$)$. Mauritius $\left(1860 \mathrm{~km}^{2}\right)$ is an older island, more eroded (highest point $828 \mathrm{~m} \mathrm{vs} 3070 \mathrm{~m}$ in Réunion) and surrounded by large lagoons, shelters 11 permanent rivers. Between these two islands, the Réunion rivers presents the steeper slopes (for the 13 rivers from the source to the sea, mean slope is $6.5 \pm$ $3.0 \%$, from 2.5 to $12 \%$ ). Abrupt slopes are mostly confined in the highest altitudes, above waterfalls $(500-600 \mathrm{~m})$. The lower courses $(<100 \mathrm{~m})$ usually show a smoother slope (for the last $4 \mathrm{~km}$ before the sea, mean slope is $2.4 \pm 2.2 \%$, from 0.2 to $7.5 \%$ ). Sampling stations staggered in altitude up to $600 \mathrm{~m}$ for the Réunion rivers, and until $310 \mathrm{~m}$ in Mauritius.

\section{Sampling protocol}

All the Réunion data were extracted from the Réunion Fish Network survey ("Réseau Piscicole Réunionnais"), lead by the Association Réunionnaise de Développement de l'Aquaculture (ARDA 1999, 2000, 2001, 2002), except in the River du Mat (Robinet et al. 2003b). At different seasons, the 13 permanent rivers in Réunion were sampled on one to four stations (Figure 1), each from 100 to $500 \mathrm{~m}$ long. Stations were sampled at exactly the same location every year. Eels were collected during low water periods using a portative electroshocker (DEKA 3000 from EFKO manufacturer), delivering electric impulsions between an anode and a cathode (30 impulsions. $\mathrm{s}^{-1}, 350 \mathrm{~V}$ and $4 \mathrm{~A}$ ). Sampling was lead in two ways: with a standardized sampling effort of $30 \mathrm{~s}$ for each sampling point (corresponding to a $5 \mathrm{~m}^{2}$ water surface, every sampling point separated one from each other by $3 \mathrm{~m}$ minimum), or with a continuous sampling throughout the whole station. Mauritius rivers were sampled with the sampling points protocol during an inventory mission in November 2002.

Data from other fish inventory campaigns were used for comparisons with those of Réunion and Mauritius. They were lead by the ARDA in Comoros (Mayotte Island, Mozambique Channel, $12^{\circ} \mathrm{S}-46^{\circ} \mathrm{E}$, Nov. 2003), by the National Museum of Natural History (NMNH, Paris - France) and the Symbiose Association in New Caledonia (South Pacific $21^{\circ} \mathrm{S}-165^{\circ} \mathrm{E}$, Mar-Apr. 1999), and the NMNH in Marquesas (South Pacific $7^{\circ} \mathrm{S}-140^{\circ} \mathrm{W}$, Hiva Oa, Tahuata and Nuku Hiva islands, Feb. 2000). Eels were collected using the same type of portative electroshocker and standard sampling protocol, but only data concerning $A$. marmorata are presented here.

All collected eels were anesthetized by clover oil in ethanol $95^{\circ}$ (Peake 1998), measured to the nearest $\mathrm{mm}$ (total length, distance between insertion of dorsal and anal fins), weighted to the nearest g, and examined for determination (tail pigmentation and dorsal coloration). Specimens were then released in the same station after awaking. We used morphometric keys proposed by Ege (1939) for species determination, crossing the back coloration, or the tail pigmentation for the youngest eels (Robinet et al. 2003ab), and the A-D ratio (ratio between anal and dorsal fins in relation to the body length). With this A-D ratio, distinction can be made between $A$. bicolor bicolor (shortfinned, A-D ratio $<2 \%$ ) and the other species (longfinned, A-D ratio $>14 \%$ for $A$. marmorata, around $14 \%$ for $A$. mossambica, $<14 \%$ for A. nebulosa labiata, see Ege 1939 for details). A. marmorata shows a mottled back, brown on a dark background, and $A$. nebulosa labiata shows slightly the same patterns in dark green, $A$. mossambica has a non-mottled nor marbled back, and A. bicolor bicolor a plain dark grey 
back. Many juvenile longfinned eels were impossible to determine in the field with these classical morphological characteristics, because the adult dorsal coloration only appears around 100-120 mm. They were therefore designated as "undetermined longfinned specimens".

The fishing efficiency of the sampling method was tested in July 2001 in the River du Mât (largest river of Réunion Island), with 3 successive passes on the same station, each of 30 sampling points with eels removal at each pass. The number of eels collected in each pass (20, 11 and 3 respectively from the $1^{\text {st }}$ to the $3^{\text {rd }}$ pass) were used in a multi-passes estimator program (Carle and Strub 1978). The total number of eels was estimated to be of 36 (out of 34 collected). The fishing efficiency for the $1^{\text {st }}$ pass represented $55.5 \%$ of the total eels estimated for all sizes (Carle and Strub 1978), and this efficiency was not affected by the eel size (57\% for eels $<200 \mathrm{~mm}$ and $55 \%$ for eels $>200 \mathrm{~mm}$ ). Similar hydrological conditions (low water level with no turbidity) were encountered during this efficiency test and the sampling campaigns. Relative densities (Catch per Unit of Effort - CPUE - for relative densities calculated from a single pass) were expressed in ind.ha ${ }^{-1}$ or in ind. $100 \mathrm{~m}^{-2}$ of water surface.

Relative biomasses, i.e. biomass collected during the single pass, were expressed in $\mathrm{kg} \cdot \mathrm{ha}^{-1}$. Estimated densities and biomasses were expressed after the efficiency correction.

Coefficients of variation $(\mathrm{CV})$ were calculated based on the relative densities of three size classes $(<250 \mathrm{~mm}, 251-400 \mathrm{~mm},>401 \mathrm{~mm})$. A sampling of at least 2 consecutive years, at the same season and strictly on the same station, makes possible a $C V$ calculation (Freeman et al. 1988, Grossman et al. 1990, Taylor and Warren 2001): with $d_{n}$ the linear relative density at the year $\mathrm{n}, C V_{(\mathrm{d} 1 \ldots \mathrm{dn})}=\left[\mathrm{SD}\left(\mathrm{d}_{1} \ldots \mathrm{d}_{\mathrm{n}}\right) /\right.$ mean $\left.\left(\mathrm{d}_{1} \ldots \mathrm{d}_{\mathrm{n}}\right)\right] * 100$.

\section{Condition factor and length-frequency decomposition}

Individual condition factors $(C F$, Ricker 1975) were calculated for $A$. marmorata in Réunion as follows: $C F=100000\left(W / L^{b}\right)$, where $L$ is total length $(\mathrm{mm}), W$ is body weight $(\mathrm{g})$ and $b$ is the slope from the (log length - log weight) regression for all A. marmorata specimens. We used a multiple regression analysis (Sokal \& Rohlf 1995) to analyze the effects of the river, the sampling date and the altitude of the station on condition factors.

In the Réunion data set, length-frequency histograms were made for each station and each year, using a class-interval of $15 \mathrm{~mm}$. Polynomial decompositions were adjusted on these time-series of length-frequency using the Bhattacharya's method (Bhattacharya 1967), that fits normal distributions on each modal-class of the length-frequency histograms. Graphic analysis were performed with the FISAT II software (Gayanilo \& Pauly 1997). Means and standard deviations of each mod were calculated. Growth rate of $A$. marmorata yellow eels was previously estimated (17.4 $\pm 3.4 \mathrm{~mm} . \mathrm{month}^{-1}$, Robinet et al. 2003b). We used this growth estimation to link the modal-class in the length-frequency histograms, like the time-size spectra diagrams of ICES (2005) and Kristensen et al. (2006), and characterize the newly recruited fraction every year.

The modal classes extinction rate was defined as the slope $(z)$ of the regression line between modal classes on each length-frequency diagram $(y=z x+b)$. In order to avoid incomplete recruitments inherent to the sampling date, the first modal class retained has been defined as the higher bar of the diagram. Such local extinction rates for A. marmorata modal classes were compared between these insular systems. 


\section{Results \\ Eel community composition}

Among a total of 1978 eels determined in Réunion and 128 in Mauritius, a majority were $A$. marmorata (Table 1). Undetermined longfinned specimens were not reported in this table. $A$. marmorata represented 91.7 and $90.7 \%$ of all the eels determined in Réunion and Mauritius respectively. The mean A-D ratio for A. marmorata was $16.7 \pm 1.0 \%$ (range 14.2-20.6), positively correlated with the total body length $\left(\operatorname{adj} . \mathrm{r}^{2}=0.141, \mathrm{p}<0.001\right)$. Other eel species collected were $A$. bicolor bicolor (shortfinned), A. mossambica (mean A-D ratio $14.0 \pm 2.2 \%$, range 8.6-17.7) and $A$. nebulosa labiata (mean A-D ratio $12.2 \pm 1.7 \%$, range $8.5-13.6$ ).

\section{Relative densities and biomasses}

The mean densities and biomasses of all species, relative and estimated, are reported in Table 2 for both Réunion and Mauritius. A. bicolor bicolor, and A. nebulosa labiata were found to be confined to the lower sections (altitude $<300 \mathrm{~m}$, Table 3), whereas A. mossambica was found in upper zones. Since A. nebulosa labiata was very rare in Réunion, no altitudinal preference can be given for this species; same observation in Mauritus, but with much less sampling stations. A. marmorata dominated in both communities. It showed a strong altitudinal gradient from the lower to the medium and upper zones, especially for the younger stages $(<250 \mathrm{~mm}$, Figure 2). $C V$ were logically higher for the lower mean densities. $C V$ stayed below $100 \%$ for the smaller and medium length $(<400 \mathrm{~mm}$, relatively stable densities $)$, but were amplified for larger eels ( $>401 \mathrm{~mm}$, unstable densities).

In the Réunion Island, the mean condition factor of $A$. marmorata was $0.112( \pm 0.017$, range 0.026-0.225), for $A$. bicolor bicolor 0.105 ( \pm 0.015 , range 0.077-0.127), and for $A$. mossambica 0.043 ( \pm 0.007 , range 0.022-0.070). There was not enough individuals of $A$. nebulosa labiata to give an estimation. The condition factor of $A$. marmorata in Réunion showed a slight positive correlation with the altitude $\left(\mathrm{r}^{2}\right.$ and $\mathrm{p}$-value both $\left.<0.05\right)$, whereas no significant difference were found among rivers nor among sampling dates.

\section{Structure of A. marmorata local populations}

For Réunion rivers, mean length ( $\pm \mathrm{sd}$ ) of each modal class was reported on a timeaxis, corresponding to the successive sampling dates for the 1999-2002 period. Assuming that growth is quite uninterrupted in tropical areas, modes were linked between successive modal classes for the River des Roches (Figure 3). With these linkages, the mean growth rate for yellow eels in the River des Roches was $14.5 \pm 3.2$ mm.month $^{-1}$ (range 10.7-19.7), in accordance with the rate estimated by otolith analysis (Robinet et al. 2003b). Successive fluvial recruitments can then be visualized (3 modal classes in July 2000, 3 in May 2001, 2 in April 2002 and 1 in October 2002). Based on this method, yearly fluvial recruitments were pointed out in 6 other rivers (Figure 4), showing every year from 1 to 4 new modal classes. No new recruits are observed from May to August (River des Roches, Figure 3), nor from May to July (River Bras-Panon, Figure 4), whereas the first new recruits are observed in October (River des Roches). The fluvial recruitment seemed then to stagger every year from at least October to approximately April.

On the length-frequency diagrams established for other insular freshwater systems (Figure 5), the Réunion and Mauritius A. marmorata show a much higher cohorts extinction rate (mean $5.34 \%$ and $3.13 \%$ respectively) than those of Marquesas (1.56\%), Comoros $(1.28 \%)$ and New Caledonia (1.47\%). 


\section{Discussion \\ Composition of the eel community in southwestern Indian Ocean freshwaters}

Compositions of the eel community are very similar between these two adjoining islands. $A$. marmorata largely dominates the community and can reach high altitude areas, whereas $A$. mossambica, A. bicolor bicolor and A. nebulosa labiata are much less abundant. If the actual composition of eel communities in the western Indian Ocean rivers are examined, two contrasted communities occur around Madagascar: one northern, dominated by A. bicolor bicolor and A. nebulosa labiata; and one southern, dominated by A. marmorata and A. mossambica (Jespersen 1942, Jubb 1961, Tesch 1977, Bruton et al. 1987, Watanabe 2003). These differences in the riverine species composition reflect those of the estuarine recruitment, a consequence of the marine routes of the leptocephalus larvae.

Given the similar species compositions in their eel community, the Réunion and Mauritius islands are obviously located in the same trail of drifting larvae. Moreover, they may be located on the southern migration route (south-east of Madagascar), because A. bicolor bicolor and A. nebulosa labiata are poorly represented there, as in the southeastern African coast (Jubb 1961). However, the dominant species is not A. mossambica, as in rivers of the southeastern African coast (Bruton et al. 1987). This could be a consequence of the twomonth interval between $A$. mossambica and A. marmorata hatching dates and arrivals to Réunion Island (Robinet et al. 2003a). Changes in the current configuration during this 2 months interval can induce a shift in the drifting routes, inducing that most of the drifting $A$. mossambica might miss these islands, but not those of $A$. marmorata.

\section{Dynamics of A. marmorata local populations}

The survey of eel local populations by electrofishing can be considered as a useful way to monitor the estuarine recruitment patterns. This was not an attempt to link size-classes to ages (we do not have any size-age key) but to visualize rhythms and periods of the annual fluvial recruitment in each river. With this aim, a low number of eels in each modal class is not a problem, because in these tropical rivers elvers have a high growth rate, making the new recruits, - smaller eels, easily visible in diagrams. However, these fluvial recruitments does not necessarily reflect exactly the estuarine recruitments, and such links between them must be investigated further. Particularly, the exact succession of estuarine recruitments cannot be surely identified without a complementary otolith microstructure analysis.

Nevertheless, this study clearly shows the fraction of A.marmorata yearly recruited in rivers, and can lead to formulate reasonable inferences relative to the fluvial recruitment period. In the Réunion rivers, between 1999 and 2002, the fluvial recruitment of $A$. marmorata staggered from October to April, during the whole cyclonic season. There was no perceptible fluvial recruitment from April to October. These patterns coincide almost exactly with the estuarine recruitment patterns observed in the River des Roches (Réunion), from November 2000 to April 2001 (Robinet et al. 2003b). They are also very similar with those observed for A. marmorata, A. megastoma and A. obscura in Tahiti (estuarine and fluvial recruitment staggered from October to April, Le Belle et al. 1987, Marquet 1987, 1992), and A. mossambica in the Eastern Cape, South Africa (estuarine recruitment from September to April, Bruton et al. 1987). Conversely, in the estuaries of Sumatra (Indonesia), the recruitment has been showed to occur all the year long, but with considerable interannual variation (Sugeha et al. 2001). Tahiti, in the Société archipelago $\left(18^{\circ} \mathrm{S}\right)$, the Réunion and Mauritius islands (around $20^{\circ} \mathrm{S}$ ) and the Eastern Cape (around $35^{\circ} \mathrm{S}$ ) are under a contrasted hydroclimatic regime, composed by a dry and a wet (cyclonic) season, whereas Sumatra $\left(0^{\circ}\right)$ 
is located in an equatorial zone, without such contrasted seasons. These differences might influence the timing of spawning migration for maturing "silver" eels, inducing the observed patterns in the subsequent estuarine recruitment.

Eel mean relative densities and biomasses were weaker in Réunion (relative biomasses 6.1 kg.ha ${ }^{-1}$, range 0-270.5) than in Mauritius rivers (11.6 kg.ha ${ }^{-1}$, range 0-50.6), with a noticeable high variability between stations. To allow the comparison with other tropical insular systems, we calculated the estimated densities and biomasses in relation with the fishing efficiency (mean $11.1 \mathrm{~kg} \cdot \mathrm{ha}^{-1}$, range $0-487.3$ for Réunion; mean $22.2 \mathrm{~kg} \cdot \mathrm{ha}^{-1}$, range $0-91.2$ for Mauritius). These estimated biomasses are comparable to those estimated by Balon (1975) in the Lake Kariba (7.5 kg.ha ${ }^{-1}$, eels maybe inhabiting only the lake edges), but both are low compared with those in the Comoros rivers (Mayotte, mean $233 \mathrm{~kg} \cdot \mathrm{ha}^{-1}$, range 16-1032, Nov. 2003, Valade \& Feunteun unpubl. data), French Polynesian rivers (mean $538.5 \mathrm{~kg}^{-\mathrm{ha}^{-1}}$ in the Society Islands, from 207 to 485 in the Austral Islands, from 267 to 742 in the Gambier Islands, from 94 to 291 in the Marquesas Islands, Marquet \& Galzin 1991). This difference may be induced by the lack of large eels (TL $>400 \mathrm{~mm}$ ) in Réunion and Mauritius rivers, which might have been caused by subsistence fisheries (field observations, no data available). The disappearance of $A$. marmorata modal classes seems to be very quick, maybe less than 3 years, as shown by the steep extinction rates, particularly when compared to other tropical insular systems where there is no traditional eel fishery (Comoros, New Caledonia and Marquesas islands, Figure 5).

\section{Local lack of future spawners and the regional panmixia hypothesis}

In A. marmorata, the sexual maturation is though to be slow (Sugeha 2003), the single maturing male captured in Réunion Island was 10 years olds and $708 \mathrm{~mm}$ long (Robinet \& Feunteun 2002; Robinet et al. 2003c). Therefore, due to the lack of such large eels in Réunion and Mauritius rivers, the local reproductive turnover is uncertain. These rivers may only have a weak contribution to the regional production of breeders of $A$. marmorata, except if there are some non-freshwater local populations in brackish systems (coastal lakes) or in coastal areas, as observed for A. japonica (Tsukamoto et al. 1998, Kotake et al. 2004, 2005). Nevertheless, this deficit in local production of spawners may not interfere with local recruitment patterns, that appeared to occur regularly throughout the cyclonic period. This observation reinforces the panmixia hypothesis at the regional scale, at least for $A$. marmorata, and pleads for a regionally mixed origin of the local recruitment.

\section{Acknowledgements}

The authors wish to thank all the scientists who contributed to samplings. The Réunion Fish Network survey was supported by the CSP, the DIREN of Réunion, the Réunion Department, the Réunion Region and the ARDA. The fish inventory campaigns in every islands except New Caledonia and Marquesas were coordinated by the ARDA. In Mauritius, it was supported by the GIP ECOFOR (French Environment Ministry [FEM]), and involved the NMNH of Paris, the ENSAT of Toulouse, the universities of La Rochelle and Montpellier 2. In Mayotte, it was supported by the Réunion Region and involved the university of La Rochelle. In the Seychelles, it was supported by the Seychelles Environment Ministry, and involved the NMHN. Those in New Caledonia and Marquesas were supported by the NMHN, the FEM, the EPHE and the Symbiose Association. Thanks to M.J. Miller (ORI, University of Tokyo) for the English revision. T. Robinet was supported by the GIP ECOFOR and a JSPS Postdoctoral Fellowship. 


\section{References}

Aoyama, J., N. Mochioka, T. Otake, I. Ishikawa, Y. Kawakami, P. Castle, M. Nishida \& K. Tsukamoto. 1999. Distribution and dispersal of anguillid leptocephali in the western Pacific Ocean revealed by molecular analysis. Mar. Ecol. Progr. Ser. 188: 193-200.

Arai, T., D. Limbong, T. Otake \& K. Tsukamoto. 1999. Metamorphosis and inshore migration of tropical eels Anguilla spp. In the Indo-Pacific. Mar. Ecol. Progr. Ser. 182: 283-293.

ARDA (Ricou, J.F., P. Bosc \& R. Cadene). 1999. Mise en place d'un réseau piscicole à la Réunion: Adaptation méthodologique d'un protocole d'échantillonnage de l'ichtyofaune. ARDA - CSP - ENSAT - DIREN - Région Réunion, Technical Report, 100 p.

ARDA (Ricou, J.F., P.Valade, H.P. Grondin \& P. Bosc). 2000. Etat référentiel des peuplements piscicoles à la Réunion, campagne d'inventaires 1999, préalable à la mise en place du réseau piscicole. ARDA - CSP - Région Réunion, Technical Report, $125 \mathrm{p}$.

ARDA (Ricou, J.F., H.P. Grondin \& P. Bosc). 2001. Réseau Piscicole, campagne 2000, synthèse des résultats. ARDA - DIREN - CSP - Région Réunion - Département de La Réunion, Technical Report, $85 \mathrm{p}$.

ARDA (Valade, P., J.F. Ricou, H.P. Grondin, P. Bosc). 2002. Réseau Piscicole, campagne 2001, synthèse des résultats. ARDA - DIREN - CSP - Région Réunion - Département de La Réunion, Technical Report, 123 p.

ARDA (Valade P., H.P. Grondin \& P. Bosc). 2003. Réseau Piscicole, campagne 2002, synthèse des résultats. ARDA - DIREN - CSP - Région Réunion - Département de La Réunion, Technical Report, $90 \mathrm{p}$.

Baissac, J. de B. 1990. Checklist of marine fishes of Mauritius. Manuscript $\mathrm{RAF} / 87 / 008 / \mathrm{WP} / 54 / 90$ in the ichthyology library of the Bernice P. Bishop Museum, Honolulu, 42pp.

Balon, E.K. 1975. The eels of Lake Kariba : distribution, taxonomic status, age, growth and density. J. Fish Biol. 7: 797-815.

Bhattacharya, C.G. 1967. A simple method of resolution of a distribution into Gaussian components. Biometrics 23: 115-135.

Blanc, M. \& E. POSTEL. 1958. Sur une petite collection de Poissons de la Réunion. Mémoires de l'Institut des Sciences de Madagascar, II(F): 367-376.

Bruton, M.N., A.H. Bok \& M.T.T. Davies. 1987. Life history styles of diadromous fishes in inland waters of southern Africa. Am. Fish. Soc. Symposium 1: 104-121.

Budimawan. 1997. The early life history of the tropical eel Anguilla marmorata (Quoy \& Gaimard, 1824) from four Pacific estuaries, as revealed from otolith microstructural analyses. J. Appl. Icht. 13: 57-62.

Cailleux, A. 1954. Limites dimensionnelles des noms des fractions granulométriques. Bull. Soc. Géol. Fr., 4: 643-646.

Carle, F.L. \& M.R. Strub. 1978. A New Method for Estimating Population Size from Removal Data. Biometrics 34: 621-630.

Dercourt, J. 1997. Les îles françaises de l'océan Indien : La réunion, Mayotte, Kerguelen, Saint Paul et Amsterdam, et l'archipel de Crozet. In: Dercourt, J. Géologie et géodynamique de la France, Dunod, Paris, Chapter 1: 3-21.

Ege, V. 1939. A revision of the genus Anguilla Shaw: a systematic, phylogenetic and geographical study. Dana Rep., C.A. Retzels (ed.), Copenhagen 16: 256 p.

Freeman, M.C., M.K. Crawford, J.C. Barrett, D.E. Facey, M.G. Flood, J. Hill, D.J. Stouder \& G.D. Grossman. 1988. Fish Assemblage Stability in a Southern Appalachian Stream. Can. J. Fish. Aquat. Sci. 45: 1949-1958.

Frost, W.E. 1954. Observations on the Biology of Eels (Anguilla spp.) of Kenya Colony. Col. Off. Fish. Pub. no. 6. 
Gayanilo, F.C. Jr. \& D. Pauly (eds.). 1997. The FAO-ICLARM Stock Assessment Tools (FiSAT) Reference Manual. FAO Computerized Information Series (Fisheries), No. 8, Rome, FAO: 262 p.

Grossman, G.D., J.F. Dowd \& M. Crawford. 1990. Assemblage Stability in Stream Fishes: A Review. Env. Mngmt 14: 661-671.

Gudger, E.W. 1929. Nicolas Pike and his unpublished paintings of fishes of Mauritius. Bull. Am. Mus. Nat. Hist. 58: 489-510.

ICES. 2005. Report of the Study Group on Age-length Structured Assessment Models (SGASAM), 14-18 March 2005, ICES Headquarters, Copenhagen Denmark. ICES CM 2005/D:01, 67p.

Ishikawa, S., K. Tsukamoto \& M. Nishida. 2004. Genetic evidence for multiple geographic populations of the giant mottled eel Anguilla marmorata in the Pacific and Indian oceans. Ichth. Res. 51: 343-353.

Jellyman, D.J. 1987. Review of the Marine Life History of Australasian Temperate Species of Anguilla. Am. Fish. Soc. Sympos. 1 (Common strategies of anadromous and catadromous fishes): 276-285.

Jespersen, P. 1942. Indo-Pacific leptocephalids of the genus Anguilla: systematic and biological studies. Dana Report 22: 1-128.

Jubb, R.A. 1960. Elvers and post-elvers of the freshwater eels of South Africa. Piscator 49: 68-76.

Jubb, R.A. 1961. The freshwater eels (Anguilla spp.) of Southern Africa : An introduction to their identification and biology. Annals of the Cape Provincial Museum 1: 15-48.

Keith, P., E. Vigneux \& P. Bosc. 1999. Atlas des poissons et crustacés d'eau douce de la Réunion. Patrimoines naturels (M.N.H.N./S.P.N.) 39: 136 p.

Kiener, A. \& P. Duchochois. 1981. Etude des problèmes piscicoles des eaux intérieures de la Réunion. CEMAGREF Aix en Provence Report, Section Qualité des eaux - Pêche et pisciculture, Study n 25:140 p.

Kotake, A., T. Arai, T. Ozawa, S. Nojima, M.J. Miller \& K. Tsukamoto. 2004. Variation in migratory history of Japanese eels, Anguilla japonica, collected in coastal waters of the Amakusa Islands, Japan, inferred from otolith Sr/Ca ratios. Mar. Biol. 142: 849-854.

Kotake, A., A. Okamura, Y. Yamada, T. Utoh, T. Arai, M.J. Miller, H.P. Oka \& K. Tsukamoto. 2005. Seasonal variation in the migratory history of the Japanese eel Anguilla japonica in Mikawa Bay, Japan. Mar. Ecol. Progr. Ser. 293: 213-221.

Kristensen, K., P. Lewy \& J.E. Beyer. 2006. Maximum likehood estimation in a size-spectra model. Can. J. Fish. Aquat. Sci. in press.

Le Belle, N., G. Marquet \& M. Fontaine. 1987. Peut-on envisager l'exploitation de certaines populations d'anguilles de Polynésie ? Bull. Soc. Etudes océaniennes (Papeete) 20: 51-56.

Marquet, G. 1987. Périlogie des anguilles de Tahiti-Moorea en Polynésie Française. Doctoral Dissertation, Ecole Pratique des Hautes Etudes (France), 151p.

Marquet, G. 1992. L'étude du recrutement et de la physiologie des anguilles de Polynésie Française permet-elle de cerner leur aire de ponte ? Bull. Inst. Océanogr. Monaco 10: 129147.

Marquet, G. \& R. Galzin. 1991. The eels of French Polynesia : Taxonomy, distribution and biomass. La mer 29: 8-17.

Marquet, G., B. Séret \& R. Lecomte-Finiger. 1997. Inventaires comparés des poissons des eaux intérieures de trois îles océaniques tropicales de l'Indo-Pacifique (La Réunion, La Nouvelle-Calédonie et Tahiti). Cybium 21(suppl. 1): 27-34.

Miller, M.J. 2003. The Worldwide Distribution of Anguillid Leptocephali. In Aida, K., K. Tsukamoto \& K. Yamauchi (Eds). Eel Biology, Chapter 11: 157-168. 
Moreau, J. 1987. Zones humides et lacs peu profonds d'Afrique. Région 9:Madagascar. Burgis et Symoens (Eds), Editions de l'ORSTOM, Travaux et Documents n²11: 595-650.

Nishi, G. \& S. Imai. 1969. On the juvenile of Anguilla marmorata Quoy \& Gaymard in Yakushima (Yaku Island). Its ecology and morphology. Mem. Fac. Fish. Kagoshima Univ. 18: $65-76$.

Peake, S. 1998. Sodium Bicarbonate and Clove Oil as Potential Anesthetics for Nonsalmonid Fishes. North Am. J. Fish. Mngt. 18: 919-924.

Ricker, W. E. 1975. Computation and uses of central trend lines. Can. J. Zool. 62: 1897-1905.

Robinet, T. \& E. Feunteun. 2002. First observations of shortfinned Anguilla bicolor bicolor and longfinned Anguilla marmorata silver eels in the Réunion island. Bull. Fr. Pêche Piscic. 364: 87-95.

Robinet, T., R. Lecomte-Finiger, K. Escoubeyrou \& E. Feunteun. 2003a. Tropical eels Anguilla spp. recruiting to Réunion Island in the Indian Ocean: taxonomy, patterns of recruitment and early life histories. Mar. Ecol. Progr. Ser. 259: 263-272.

Robinet, T., S. Guyet, G. Marquet, B. Mounaix, J.M. Olivier, K. Tsukamoto, P. Valade \& E. Feunteun. 2003b. Elver invasion, population structure and growth of marbled eels Anguilla marmorata in a tropical river on Réunion island in the Indian Ocean. Env. Biol. Fish. 68: 339-348.

Robinet, T., M. Sbaihi, S. Guyet, B. Mounaix, S. Dufour \& E. Feunteun. 2003c. Advanced sexual maturation before marine migration of tropical eels Anguilla bicolor bicolor and $A$. marmorata in Réunion Island. J. Fish Biol. 63: 538-542.

Sokal, R.R. \& F.J. Rohlf. 1995. Biometry: the principles and practice of statistics in biological research, 3rd ed., Freeman, W.H. and Company, State University of New York.

Starmülhner, F. 1979. Results of the austrian hydrobiological mission, 1974, to the Seychelles, Comores and Mascareignes archipelago. Part I: preliminary report. Annales des Naturhistorischen Museums Wien 82: 621-742.

Sugeha, H.Y., T. Arai, M.J. Miller, D. Limbong \& K. Tsukamoto. 2001. Inshore migration of the tropical eels Anguilla spp. recruiting to the Poigar River estuary on north Sulawesi Island. Mar. Ecol. Progr. Ser. 221: 233-243.

Sugeha, H.Y. 2003. Life History of Tropical Eel Anguilla marmorata in the Indonesian Waters. Doctoral Dissertation. The University of Tokyo (Japan), 164p.

Tabeta, O., T. Tanimoto, T. Takai, I. Matsui \& T. Imamura. 1976. Seasonal Occurrence of Anguillid Elvers in Cagayan River, Luzon Island, the Phillipines. Bull. Jap. Soc. Sci. Fish. 42: 421-426.

Taylor, C.M. \& M.L. Warren Jr. 2001. Dynamics in species composition of stream fish assemblages: environmental variability and nested subsets. Ecology 82: 2320-2330.

Tesch, F.W. 1977. The Eel. Biology and management of anguillid eels. Chapman \& Hall (Ed.), London.

Tsukamoto, K., I. Nakai \& F.W. Tesch. 1998. Do all freshwater eels migrate? Nature 396: 635-636.

Tzeng, W.N., P.W. Cheng \& F.Y. Lin. 1995. Relative abundance, sex ratio, population structure of japanese eel Anguilla japonica in Tanshui River system of northern Taiwan. J. Fish Biol. 46: 183-201.

Watanabe, S. 2003. Taxonomy of the Freshwater Eels, Genus Anguilla Schrank, 1798. In Aida, K., K. Tsukamoto \& K. Yamauchi (Eds). Eel Biology, Chapter 1:3-18.

Williamson, G.R. \& J. Boëtius. 1993. The Eels Anguilla marmorata and A. japonica in the Pearl River, China, and Hong Kong. Asian Fisheries Science 6: 129-138. 


\section{Figures captions}

Figure 1. Location of the Réunion and Mauritius islands in the western Indian Ocean. Sampling stations are designated by black dots.

Figure 2. Mean relative densities (Ln [densities +1], ind./100 $\mathrm{m}^{2}$, left diagrams) and corresponding variation coefficients (right diagrams) of 3 length classes of $A$. marmorata with altitude in the Réunion rivers, based on 1250 eels collected during the Réunion Fish Network survey 1999-2002.

Figure 3. Length-frenquency decomposition of A. marmorata in the River des Roches (Réunion Island) from July 1999 to October 2002, assessed by the Bhattacharya's method (left diagram); links were established between the supposed identical modal-classes (mean \pm sd), according to growth rate and time between samplings (right diagram). Growth rates out of the estimated range (Robinet et al. 2003b, i.e. lower than $10 \mathrm{~mm} . \mathrm{month}^{-1}$ or higher than 20 mm.month ${ }^{-1}$ ) are not figured. New fluvial recruits are encircled.

Figure 4. Supposed identical modal-classes (mean $\pm \mathrm{sd}$ ) of $A$. marmorata linked for 6 rivers in the Réunion Island, according to growth rate and time between samplings. Out-ranged growth rates are not figured. In every river, 2, 3 or 4 new cohorts can recruit every year (encircled).

Figure 5. Length-frequency diagrams of A. marmorata for the Réunion, Mauritius, Comoros, Marquesas and New Caledonia rivers, in percent of the total eels collected. For the Réunion Island, rivers were grouped within a limited time-interval of sampling ( $<3$ months). Large $A$. marmorata (TL $>450 \mathrm{~mm}$ ) are lacking in the Réunion rivers, and, in a less proportion, in Mauritius, whereas they are well represented in other islands. Comparing the modal classes extinction rate $(z)$, the Réunion and Mauritius Islands $A$. marmorata show a much steeper one (mean 5.34\% and 3.13\% respectively) than those of Marquesas (mean 1.56\%), Comoros $(1.28 \%)$ and New Caledonia (1.47\%) Islands. 

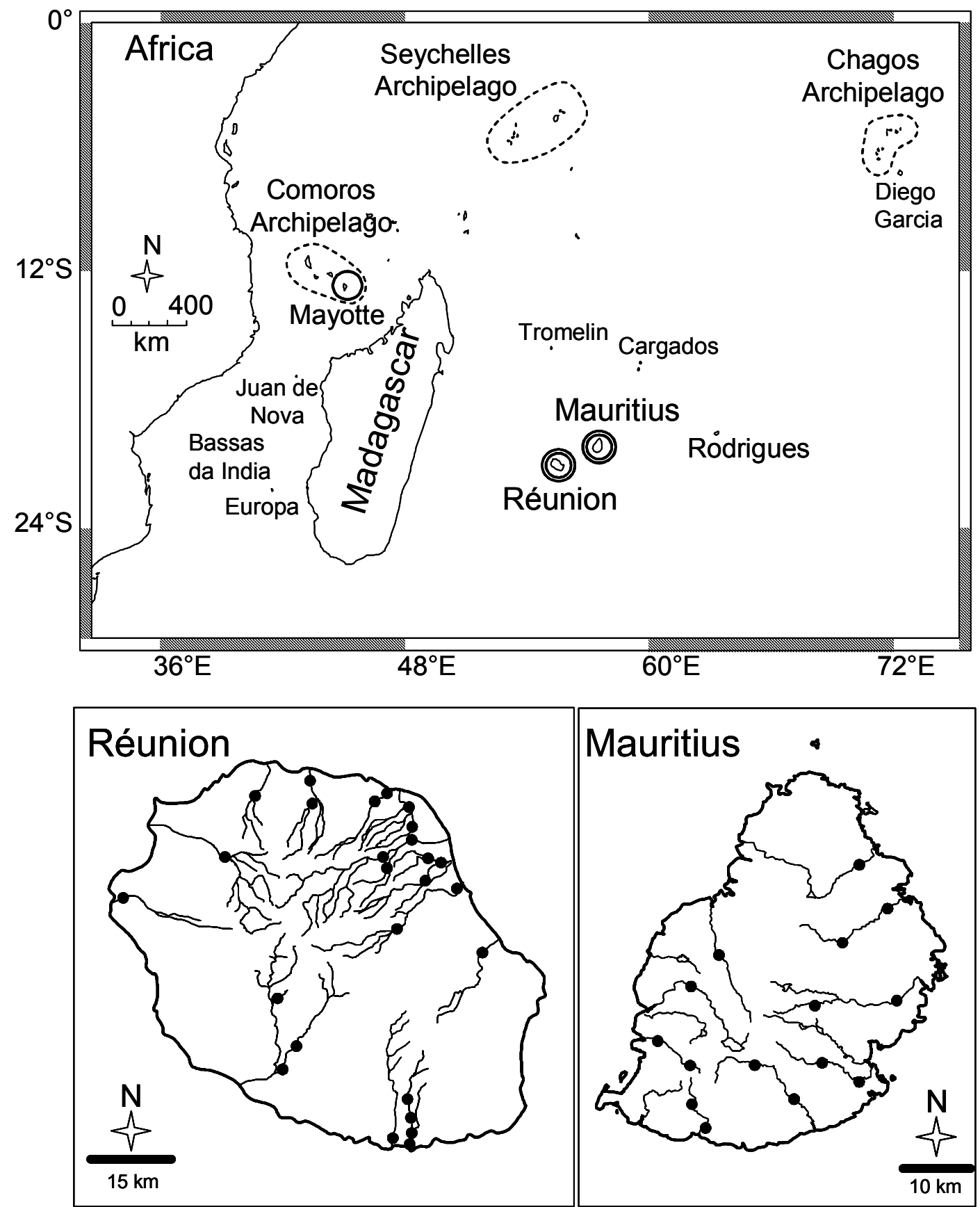

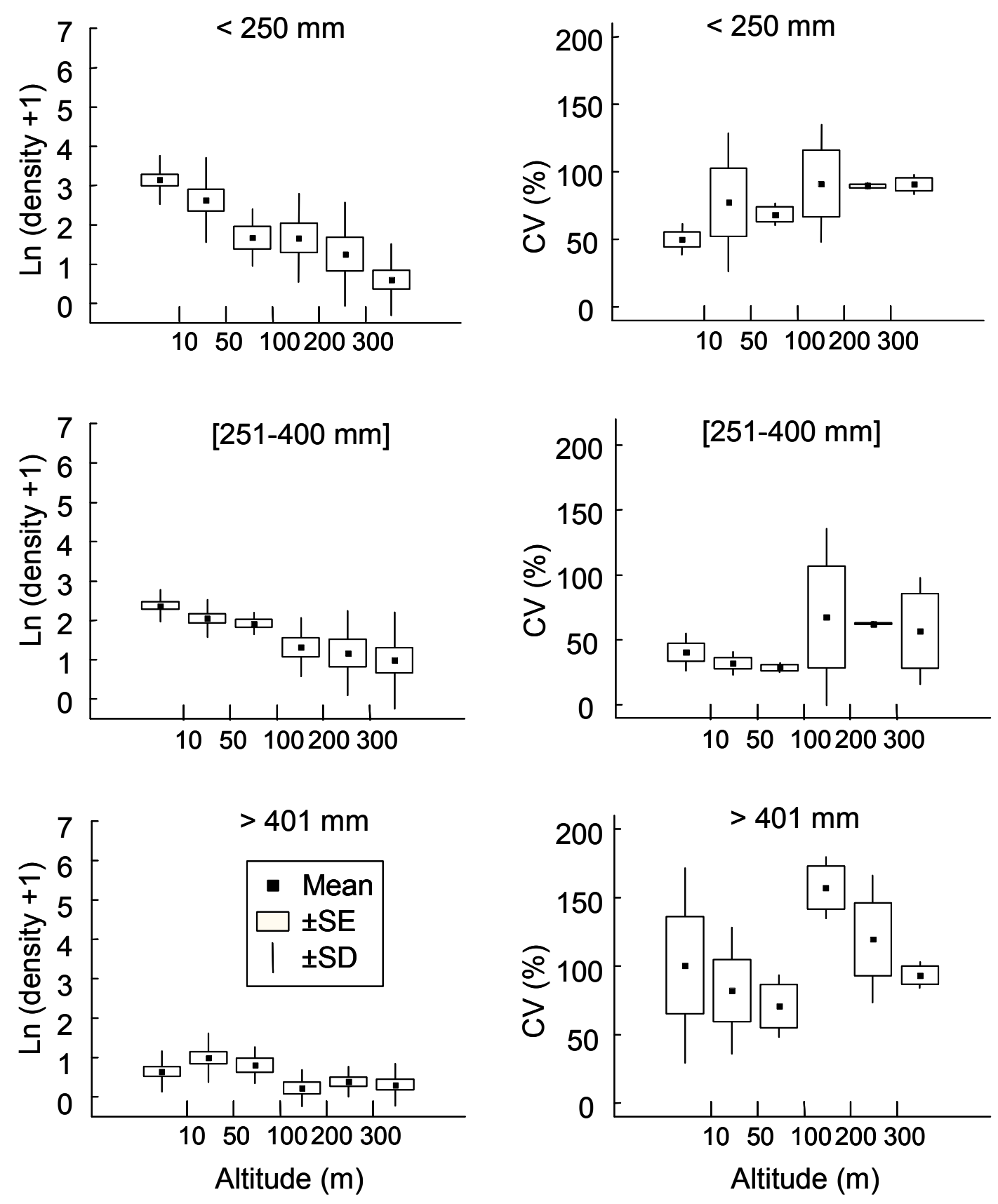


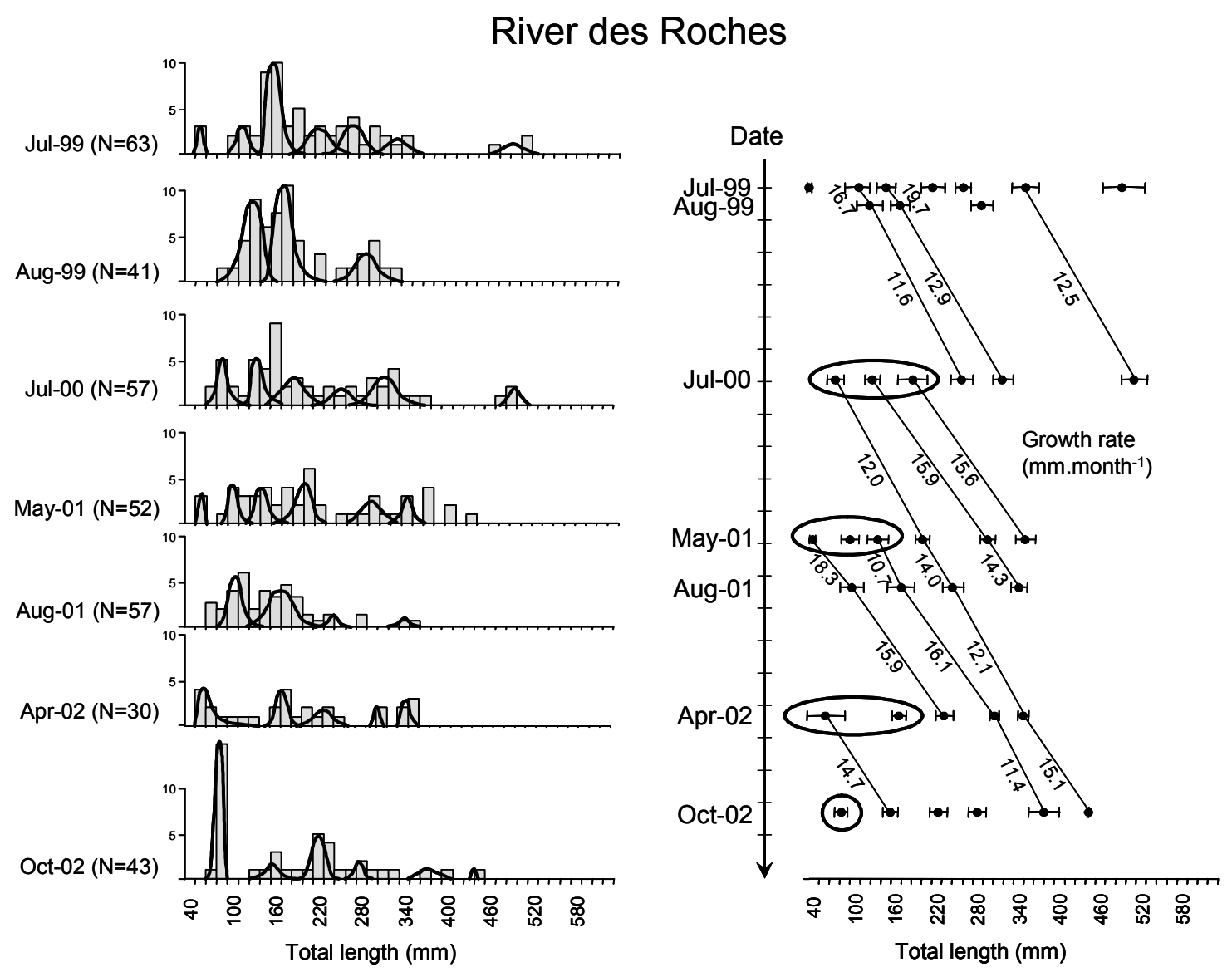



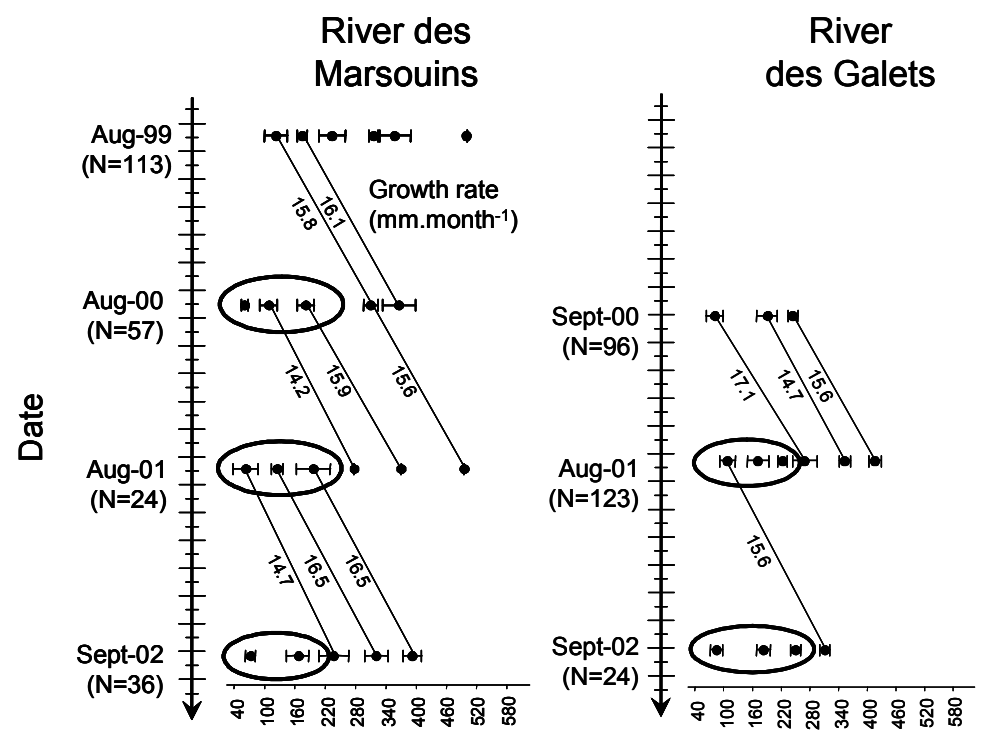

River St-Jean
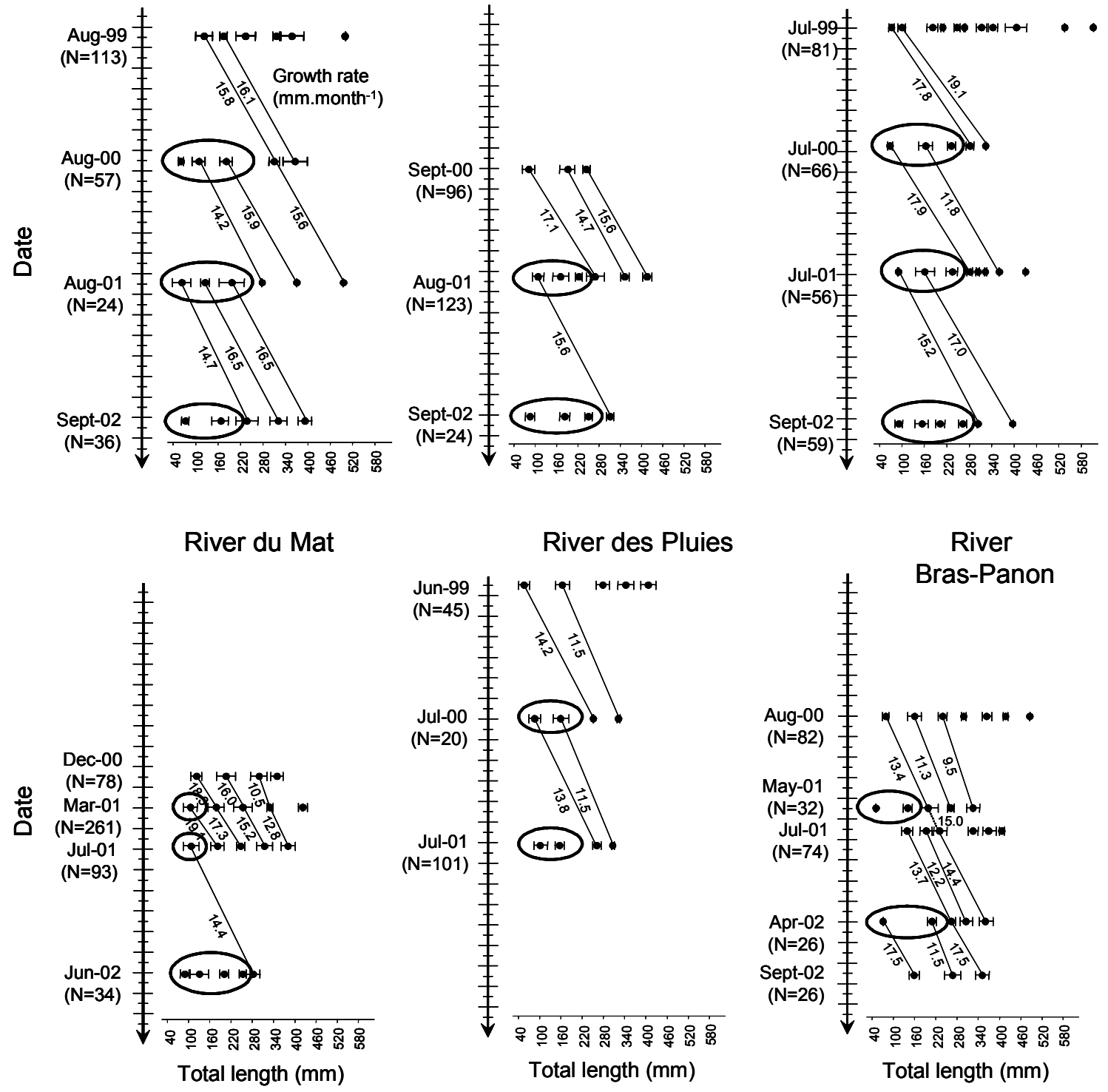

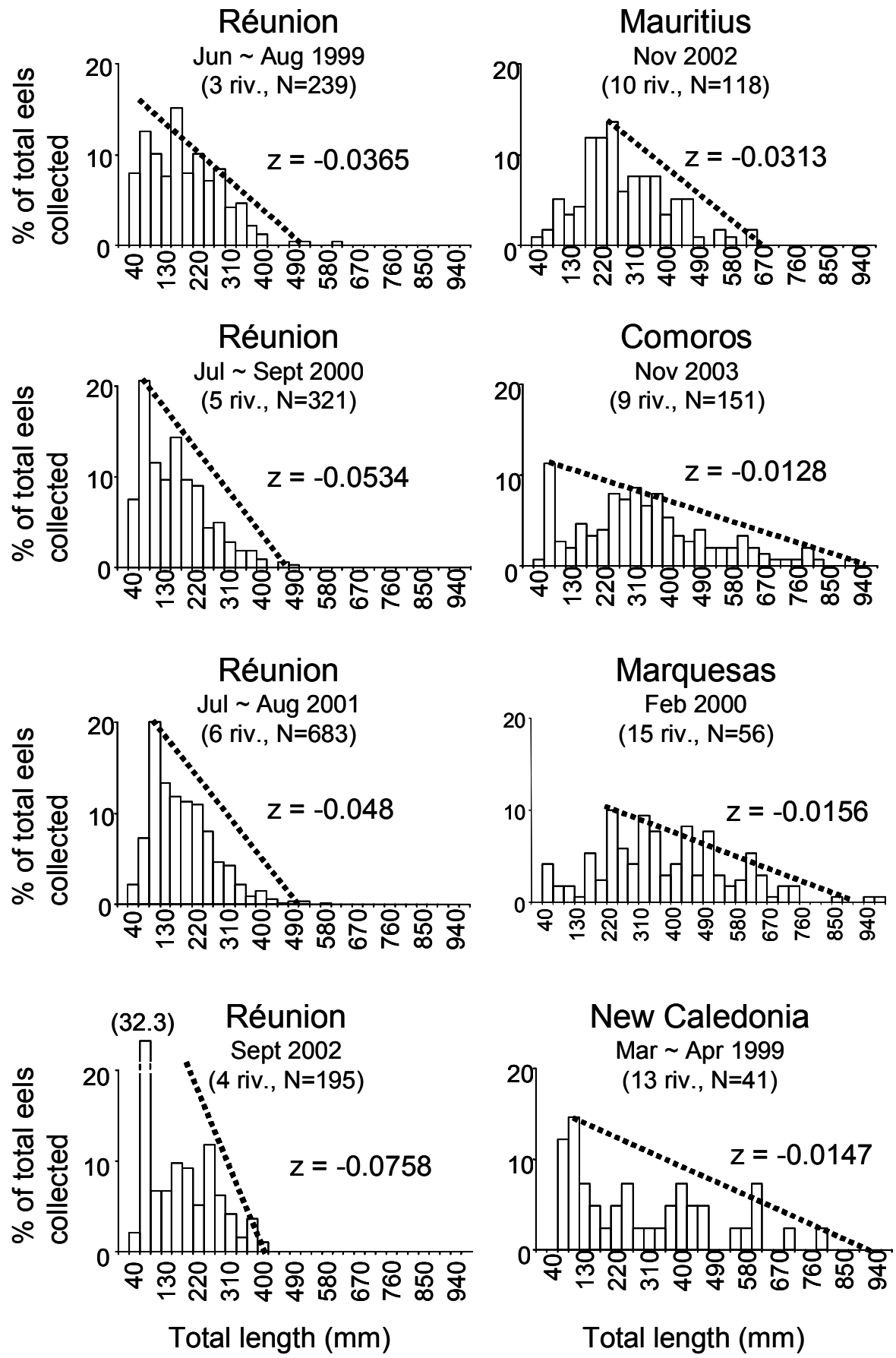


\begin{tabular}{llcccc}
\hline Location & Source & $\begin{array}{c}\text { A. bicolor } \\
\text { bicolor }\end{array}$ & $\begin{array}{c}\text { A. } \\
\text { marmorata }\end{array}$ & $\begin{array}{c}\text { A. } \\
\text { mossambica }\end{array}$ & $\begin{array}{c}\text { A. nebulosa } \\
\text { labiata }\end{array}$ \\
\hline Réunion $^{1}$ & this study & $2.0 \%$ & $\mathbf{9 1 . 7 \%}$ & $5.6 \%$ & $0.7 \%$ \\
Mauritius $^{2}$ & this study & $0.8 \%$ & $\mathbf{9 0 . 7 \%}$ & $6.2 \%$ & $2.3 \%$ \\
Seychelles (Mahé) $^{3}$ & Valade et al. (unpubl.) & $\mathbf{1 0 0 \%}$ & - & - & - \\
Comoros (Mayotte) $^{4}$ & Valade et al. (unpubl.) & $3.2 \%$ & $\mathbf{9 6 . 1 \%}$ & $0.6 \%$ & - \\
South Africa & (Bruton et al. 1987) & $0.6 \%$ & $9.7 \%$ & $\mathbf{8 6 \%}$ & $3.7 \%$ \\
\hline
\end{tabular}

Table 1. Relative proportions of the 4 Anguillid species in freshwaters of some locations around Madagascar (yellow eels collected upper the freshwater limit). Sources : ${ }^{1}$ Réunion Fish Network survey (1999-2002, N determined=1978); ${ }^{2}$ inventory mission in Mauritius (November 2002, $\mathrm{N}$ determined=128); ${ }^{3,4}$ inventory campaigns in November 2003 (see the Acknowledgements section for the details). For the Réunion, Mauritius and Mayotte Islands, undetermined longfinned eels were not included in these proportions. 


\begin{tabular}{|c|c|c|c|c|c|c|c|}
\hline & & $\begin{array}{c}\text { A. bicolor } \\
\text { bicolor }\end{array}$ & $\begin{array}{c}A . \\
\text { marmorata }\end{array}$ & $\begin{array}{c}A . \\
\text { mossambica }\end{array}$ & $\begin{array}{c}\text { A. } \\
\text { nebulosa } \\
\text { labiata }\end{array}$ & $\begin{array}{l}\text { Undet. } \\
\text { longfin. } \\
\text { eels }\end{array}$ & $\begin{array}{l}\text { Total } \\
\text { eels }\end{array}$ \\
\hline \multirow{6}{*}{$\begin{array}{l}\text { Réunion } \\
\text { Island }\end{array}$} & \multicolumn{7}{|c|}{ Relative density in rivers (ind./ha, mean \pm sd, max.) } \\
\hline & $\begin{array}{l}\text { Single pass } \\
\text { (CPUE) }\end{array}$ & $\begin{array}{c}2.8 \\
( \pm 16.5 \\
183.1)\end{array}$ & $\begin{array}{c}162.7 \\
( \pm 432.5 \\
5158.7)\end{array}$ & $\begin{array}{c}11.4 \\
( \pm 45.1 \\
404.0)\end{array}$ & $\begin{array}{c}1.6 \\
( \pm 17.6 \\
276.5)\end{array}$ & $\begin{array}{c}67.0 \\
( \pm 261.0 \\
3759.4)\end{array}$ & $\begin{array}{c}245.5 \\
( \pm 773.0 \\
9781.8)\end{array}$ \\
\hline & Estimated & $\begin{array}{c}5.1 \\
( \pm 29.6 \\
329.9)\end{array}$ & $\begin{array}{c}293.2 \\
( \pm 779.4 \\
9295.0)\end{array}$ & $\begin{array}{c}20.5 \\
( \pm 81.3 \\
728.0)\end{array}$ & $\begin{array}{c}2.8 \\
( \pm 31.7 \\
498.2)\end{array}$ & $\begin{array}{c}120.7 \\
( \pm 470.8 \\
6773.7)\end{array}$ & $\begin{array}{c}442.2 \\
( \pm 1392.9 \\
17624.8)\end{array}$ \\
\hline & \multicolumn{7}{|c|}{ Relative biomass in rivers $(\mathrm{kg} / \mathrm{ha}$, mean $\pm \mathrm{sd}$, max.) } \\
\hline & $\begin{array}{l}\text { Single pass } \\
\text { (CPUE) }\end{array}$ & $\begin{array}{c}<0.1 \\
(-, 1.8)\end{array}$ & $\begin{array}{c}5.5 \\
( \pm 16.8 \\
228.3)\end{array}$ & $\begin{array}{c}0.4 \\
( \pm 2.4 \\
31.9)\end{array}$ & $\begin{array}{c}<0.1 \\
(-, 3.7)\end{array}$ & $\begin{array}{c}0.1 \\
( \pm 0.4 \\
4.8)\end{array}$ & $\begin{array}{c}6.1 \\
( \pm 20.1 \\
270.5)\end{array}$ \\
\hline & Estimated & $\begin{array}{c}<0.1 \\
(-, 3.3)\end{array}$ & $\begin{array}{c}10.0 \\
( \pm 30.3 \\
411.3)\end{array}$ & $\begin{array}{c}0.8 \\
( \pm 4.3 \\
57.5)\end{array}$ & $\begin{array}{c}<0.1 \\
(-, 6.6)\end{array}$ & $\begin{array}{c}0.2 \\
( \pm 0.7 \\
8.7)\end{array}$ & $\begin{array}{c}11.1 \\
( \pm 36.2 \\
487.3)\end{array}$ \\
\hline \multirow{6}{*}{$\begin{array}{l}\text { Mauritius } \\
\text { Island }\end{array}$} & \multicolumn{7}{|c|}{ Relative density in rivers(ind./ha, mean \pm sd, max.) } \\
\hline & $\begin{array}{l}\text { Single pass } \\
\text { (CPUE) }\end{array}$ & $\begin{array}{c}0.2 \\
( \pm 0.9 \\
3.5)\end{array}$ & $\begin{array}{c}146.8 \\
( \pm 244.8 \\
933.3)\end{array}$ & $\begin{array}{c}9.3 \\
( \pm 19.8 \\
66.3)\end{array}$ & $\begin{array}{r}1.0 \\
( \pm 3.3 \\
13.0)\end{array}$ & $\begin{array}{c}2.3 \\
( \pm 5.1 \\
15.9)\end{array}$ & $\begin{array}{c}159.6 \\
( \pm 243.7 \\
933.3)\end{array}$ \\
\hline & Estimated & $\begin{array}{c}0.4 \\
( \pm 1.6 \\
6.3)\end{array}$ & $\begin{array}{c}264.4 \\
( \pm 441.0 \\
1681.7)\end{array}$ & $\begin{array}{c}16.8 \\
( \pm 35.6 \\
119.4)\end{array}$ & $\begin{array}{c}1.9 \\
( \pm 6.0 \\
23.4)\end{array}$ & $\begin{array}{c}4.1 \\
( \pm 9.1 \\
28.7)\end{array}$ & $\begin{array}{c}287.6 \\
( \pm 439.0 \\
1681.7)\end{array}$ \\
\hline & \multicolumn{7}{|c|}{ Relative biomass in rivers (kg/ha, mean $\pm \mathrm{sd}$, max.) } \\
\hline & $\begin{array}{l}\text { Single pass } \\
\text { (CPUE) }\end{array}$ & $<0.1$ & $\begin{array}{c}10.7 \\
( \pm 13.9 \\
50.6)\end{array}$ & $\begin{array}{c}0.8 \\
( \pm 2.5,9.2)\end{array}$ & $<0.1$ & - & $\begin{array}{c}11.6 \\
( \pm 13.8 \\
50.6)\end{array}$ \\
\hline & Estimated & $<0.1$ & $\begin{array}{c}20.5 \\
( \pm 25.3 \\
91.2)\end{array}$ & $\begin{array}{c}1.6 \\
( \pm 4.5 \\
16.7)\end{array}$ & $<0.1$ & - & $\begin{array}{c}22.2 \\
( \pm 25.0 \\
91.2)\end{array}$ \\
\hline
\end{tabular}

Table 2. Mean relative and estimated densities and biomasses of eels in Réunion and Mauritius rivers. Relative density is the no. eels collected during the single electrofishing pass, reported to the surface unit (i.e. CPUE), whereas estimated density was corrected by a Carle and Strub (1978) estimator of efficiency. Undet. longfin. eels: undetermined longfinned eels. 


\begin{tabular}{lcccc}
\hline Altitude $(\mathrm{m})$ & $\begin{array}{c}\text { A. marmorata } \\
(\mathrm{N}=1250)\end{array}$ & $\begin{array}{c}\text { A. mossambica } \\
(\mathrm{N}=79)\end{array}$ & $\begin{array}{c}\text { A. bicolor bicolor } \\
(\mathrm{N}=28)\end{array}$ & $\begin{array}{c}\text { A. nebulosa labiata } \\
\end{array}$ \\
& $23.0( \pm 22.9)$ & $1.8( \pm 3.1)$ & $0.6( \pm 1.3)$ & $(\mathrm{N}=5)$ \\
$<100$ & $10.3( \pm 11.6)$ & $0.4( \pm 1.0)$ & $0.1( \pm 0.3)$ & $0.1( \pm 0.6)$ \\
$>100<200$ & $10.9( \pm 11.5)$ & $0.1( \pm 0.3)$ & $0.1( \pm 0.4)$ & 0 \\
$>200<300$ & $58.9( \pm 40.5)$ & $0.4( \pm 0.7)$ & 0 & 0 \\
$>300<400$ & 0 & 0 & 0 & 0 \\
$>400<600$ & $28.0( \pm 19.9)$ & $0.6( \pm 1.0)$ & 0 & 0 \\
$>600$ & & &
\end{tabular}

Table 3. Distribution of eel species with altitude in the Réunion rivers (mean relative densities in stations $\pm \mathrm{sd}$, ind./100m², Réunion Fish Network survey 1999-2002). 